\author{
УДК 334.7 \\ JEL H890, L390 \\ ORCID ID 0000-0001-8498-6441 \\ DOI https://doi.org/10.17721/tppe.2021.43.24
}

\author{
Butenko N., Doctor of Economics, Professor, \\ Taras Shevchenko National University of Kyiv, Ukraine \\ Robins E., PhD Student, \\ Taras Shevchenko National University of Kyiv, Ukraine
}

\title{
INTERNATIONAL PUBLIC PRIVATE PARTNERSHIPS EXPERIENCES IN PORTS AND THEIR RELATION TO UKRAINE
}

The purpose of this article is to review recent international studies on ports that have entered into public private partnerships (PPPs). This article examines five articles covering ports in Columbia, Mexico, Brazil, the Caribbean (Cayman Islands), China, South Korea, and France. Divided as follows, the article includes: (I) a summary of each article; (II) a critique of the articles related to the countries referenced; and (III) an assessment of how this relates and/or applies to Ukraine. The analysis and assessment of each article should better inform progress towards PPPs and their use in ports in Ukraine.

Based on five variables to assess PPP projects in this article: (a) the type of PPP (allowing for a plurality of PPP arrangements); (b) regulatory framework (with a supportive institutional arrangement for PPPs); (c) financial safeguards (delivering value for money against other options); (d) accountability; and (e) miscellaneous data (something that improves context and practical aspects), this article offers three key findings. First, enhance accountability and publicity. Second, improve market engagement. Third, correct implementation of legal and institutional frameworks.

This study, according to its author, encountered the usual limitations: sample selection and access to data at different stages of the project's completion. The sample is fair, comprising a diverse, representative pool of projects. Regarding access to data, the article found that publicity and reporting need to improve in the Caribbean. The author engaged with all main sources, especially local ones, at different stages of each project. PPPs in the Caribbean are not exempt when it comes to budgetary decisions.

Key Words: Public Private Partnerships, Ports, Ukraine

Problem statement. Ports, whether inland or on the sea, have been critical to the economies of these countries. They can serve as the welcome or entry point to a country. The issue of how welcoming a country is, can depend upon the structure of a port. And how a port is structured directly relates to government policy and the private sector response. Whether Columbia, Brazil, Mexico, Canada, China, France, or the Caribbean (Cayman Islands), government policy must be cognizant of its impact. Therefore, it is important to make sure PPP policy is clear and accurate due to the tax and economic implications.

But should any be followed?

To properly assess ports in France, more information from the public entities or private entities associated with PPPs is needed. This article examined limited information, only 
considering a few ports in France. There also is limited information concerning the selection process of the private partners in France.

Literature review. (a) Chechurina, M N and Grin, A A. (August 2020). "Public Private Partnership in Management of Ports of the World." IOP Conference Series Earth and Environmental Science, 539(1):012144;

(b) Yareth Vargas Lopez, Erendira and Lee, Shin-Kyuo. (June 2019) "Public-Private Partnerships in Mexico, Panama, and Brazil: A Focus on Port Performance." Journal of Korea Trade, Vol. 23, No. 4, pp. 17-29;

(c) Panades-Estruch, Laura. (March 2021) "Public-Private Partnerships in Transport: A Critical Assessment of the Caribbean." Public Administration and Policy: An Asia-Pacific Journal, Vol. 24 No. 1, pp. 61-75;

(d) Ravi, Dr Lekha. (July 2019). "Private Sector Participation in International Ports: The PPP Experience and the Road Ahead." International Journal of Innovative Science and Research Technology, Vol. 4, Issue 7, pp. 347-352;

(e) Fredouet, Charles H., Guerin, Frank, and Desplebin, Olivier. (January 2016). "Implementing Public-Private Partnerships: The Case of French Port Authorities." International Journal of Applied Logistics. 6(1), pp. 31-46.

Unresolved part of the problem. There is then a short discussion on port governance and the inclination towards private sector participation. The author believes the structure of public ports changed due to the "competition and availability of private enterprise in infrastructure management" [2]. This led to public entities becoming landlords. Eventually this transformed public entities into corporate entities and then to PPPs, particularly in the services side of ports. There is a good outline of the types of PPP models, with clear definitions. There also are examples of the privatization efforts among different nations and the various conflicts that arose. It does note most of the largest ports operate under a landlord model, where "the public authority owns the port and provides the basic infrastructure and management of the marine side assets, while the private sector through concessions...operates the container terminals with their own equipment and superstructure" [2]. The article also notes the "runaway success" from privatization stems from the ability of the private entity to collect usage fees for the port.

But at the same time, the article notes the success of China's ports, which operate as joint ventures with the government, rather than as landlord-tenant structures. The success of the ports of Hong Kong and Shanghai, according to the author, can be partly due to their PPP structure. Without thorough analysis to support this, the author claims that the Port of Hong Kong's success stems from its privatization policies. Described as investor-friendly and free from government interference, a public entity owns the port, while private entity operates it. The author also references the Port of Shanghai as a successful PPP without offering any evidentiary support.

The purpose of this paper is to review recent international studies on ports that have entered into public private partnerships (PPPs).

Research methodology. The theoretical background and methodology of the paper is based on a set of general and specific methods, principles, rules and techniques of scientific research, justified by given topic and purpose. According to the conceptual 
scheme of scientific research, the following methods are used in the work: deduction, generalization, analysis, formalization and interpretation.

Findings of the study. Chechurina and Grin (2020) discusses cases of PPP ports, primarily in Canada and Columbia. But details as to its analysis are absent in this article. In Columbia, notably the Port of Cartagena, located on the Atlantic Ocean, is the focal point of this article. Beginning in 1993, Columbia began the process of privatization of its ports (including Cartagena). This stemmed from a law permitting private regional concessions, providing the administration and management of ports. It addressed low productivity, lack of security and high prices. From 1993 to the early 2000s, public and private sources invested more than $\$ 150$ million in the Port of Cartagena. According to Chechurina and Grin, "[the cost of vessels handling declined significantly, effectiveness increased more than 7 times, tariffs on usage of berths...decreased, [and] the time of berths waiting for handling reached 0." [3]. Cartagena, according to these authors, has now become one of the "best container terminals" in the Caribbean. Its operation is loosely based upon PPP structure for concessions.

The article then analyses a deep-water artic port in Canada, the Port of Churchill. This port, specializing in grain carriage, has access to the interior of Canada through railroads. A US company took control of the port in 1997. But in 2016, the company closed the port and weather destroyed the rail line. In 2018, Arctic Gateway Group Limited Partnership, a PPP itself, took control of the operation of the port. Canada provided $\$ 10$ million for the Artic Gateway Group, to allow it an opportunity to receive commercial loans [3]. The authors believe this port has potential for growth but offered scant evidence to support this claim.

There is then a mention of the positive experience at Russia's Port of Murmansk with PPPs. But the authors provide few details on the history. The authors note projects at the port involved a modernization with the establishment of a coal terminal at the port and surmise that the port should become "an international marine port-hub" [3]. Again, there is scant evidence to support this claim.

In general, this article cites the positive experiences of PPP in ports but provides limited data to support these claims. The authors note PPPs in port management aim to increase efficiency, decrease the financial burden on government, and limit political influence. The landlord type model is the most common form of port management, according to the article. This is where a public entity owns the port and private companies run it. There are loose references to this model and the article goes into detail outlining this model's use in several PPP projects around the world. PPPs, which have many definitions, as in Columbia, showcase the relative flexibility of them, both in definition and use. Still, this article must articulate this to showcase this and the other benefits of PPPs. Regardless, the modernization of ports through PPP structures in these countries led to increased investments that changed the structure of ports.

(b) Yareth Vargas Lopez and Lee (2019) in a case study, examine ports in Mexico, Panama, and Brazil. These are the top three countries for container throughput and volume in Latin America. The article looks at how the amount of private investment received influences port performance, and whether the private investment has achieved its desired 
purpose in port development. The article notes enhancements in logistics performance and quality of port infrastructure benefit the economy. There also is a brief review of South Korea as a comparison (as it encountered similar problems in port development). The article also documents different studies, some referencing the problems of PPPs due to conflicts of interest among partners, or where governments provide excessive guarantees to make projects more attractive to private investors.

But the article clearly outlines the "Latin American" style for port development with regards to PPPs. The article cites Hoffmann (2001) who discusses this Latin American model for PPPs. "The model consists of five characteristics: (1) the landlord type in most ports, with concessions for periods between 12 and 30 years and a mono operating system (the operator who had the concession was also providing the stevedoring services at a terminal); (2) a private specialized port and terminals; (3) new private ports; (4) strong foreign participation compared to other regions; and (5) except for Panama, in Latin America there were no hub ports competing with other ports" [4]. Specifically, in Latin America, ports slowly moved to a landlord-tenant model, allowing the leasing of concessions to the private sector (resulting from a legal reform process). In Brazil, the dissolution of state-owned port companies began in 1990. This boosted private sector participation. In Mexico, port reforms in 1993 led to increased investments and guarantees to develop terminals. In Panama, the International Development Bank (IDB) in 1995, developed plans to offer concessions in ports. But it is Brazil that received the highest level of private investments among these countries. These countries relied upon build/rehabilitate, operate, transfer model for greenfield/brownfield investments. The article measures port performance based upon: (1) quality of port infrastructure index (Panama had the lowest investment level with the highest quality port infrastructure); (2) container throughput, or the amount of containers received (Panamanian ports were top ranked); and (3) logistics performance, where the quality of ports performance and logistics performance are linked [4]. Panama ranked the highest overall for logistics performance index, due to its efficiency of customs, quality of trade/transport infrastructure, ease of arranging competitively priced services, competitiveness, ability to track and trace, and frequency and expected delivery times. Panama's growth may also be partly due to its geographical location.

The article notes factors that can strengthen "relationships between the public and private sectors" [4]. In particular, the article cites the need for government to have clear and transparent policies such as offering concessions with standardized criteria. Full disclosure (thereby limiting information asymmetry) in a standardized process should help limit bribery, corruption, or formation of monopolies. In addition, there is a need for "adequate legislation that manages private investment, as well as evaluates and monitors the progress of projects in the port sector" [4]. Finally, there should be "cooperation among stakeholders for policies and research that aid port efficiency" [4].

The conclusions drawn from this article are: (1) there is significant variance in PPP investments among these countries; (2) Panama outperformed the others in terms of port quality performance and logistics; and (3) to be attractive on the global stage, adoption of third generation smart ports is necessary to improve efficiency. Some takeaways, 
according to these authors, are the success of PPPs relates to governance, cooperation among stakeholders, and the level of transparency in awarding concessions. Also, in port development and competitiveness, the article notes that factors other than PPP are relevant, notably quality infrastructure.

(c) Panades-Estruch Truman (2021) critically analyses the extent to which selected PPP transportation projects in the Caribbean embrace good practices and how they benefit the public sector. The Caribbean brings development challenges to PPPs due to remote and uncompetitive markets, large public sectors, and high tariffs/fees. But PPPs have a strategic role to play in the Caribbean where countries are tax neutral with fiscal restraint. As a result, these countries seek innovative ways for projects with high initial investments. Infrastructure in the Caribbean also lags international standards. This includes lack of technical expertise in PPPs, risk assessment flaws, needed legal reform, limited ability to transfer risk to the private sector, and addressing the risks faced by local government.

Despite the commentary on other types of transport, this review focuses only on PPP in ports. So, the analysis of this article covers the case of the Cayman Islands' experience with PPPs and ports. The Caymans have PPP regulation but rely on general procurements for PPPs. Their main PPP port is a 25-year redevelopment PPP contract, a Design-BuildFinance-Operation [5]. Verdant Isle Port Partners, as part of a consortium of four companies led by Carnival and Royal Caribbean, won this contact in 2019 [5]. The project is a contractual PPP, detailing the regime of rights and obligations of the parties. But the port is a pure PPP, with a "continuous partnership that keeps the public and the private sector partners cooperating through the project tenure" [5].

There is a discussion as to the rules for PPPs in the Cayman Islands in the article. Notably, PPP costs must "not exceed $80 \%$ of operating revenue and ability to borrow to fund capital expenditure restricted to projects with sufficient expected revenues. Four PPPspecific financial safeguards include: (1) "a sound appraisal underpinning the proposed project" justifying the need for the project; (2) "improved value for money against a conventionally financed alternative" for PPP projects; (3) demonstrating the long-term financial viability of the project; and (4) "an independent opinion [...] from a qualified accountant of good standing on the correct accounting treatment in the Cayman Islands Government's accounts" [5]. There are also administrative bodies to provide training and guidance, as well as to review contracts/awards. In general, these bodies help improve public procurement.

With regards to the Cayman port, the article notes the timing of the project's start date only requires voluntarily compliance with the Cayman's legal framework. "Thus, compliance relies on the Government's goodwill, rather than the law" [5]. The Cayman Islands, according to the author, appears better prepared than in action. Their procurement framework, reliant on legislation, is up to the task, but its civil servants still learn about procurement. So, the system remains untested, and PPPs are viewed as a last resort, not a default option.

Conclusions. Based on five variables to assess PPP projects in this article: (a) the type of PPP (allowing for a plurality of PPP arrangements); (b) regulatory framework (with a supportive institutional arrangement for PPPs); (c) financial safeguards (delivering value 
for money against other options); (d) accountability; and (e) miscellaneous data (something that improves context and practical aspects), this article offers three key findings. First, enhance accountability and publicity. Second, improve market engagement. Third, correct implementation of legal and institutional frameworks [5].

This study, according to its author, encountered the usual limitations: sample selection and access to data at different stages of the project's completion. The sample is fair, comprising a diverse, representative pool of projects. Regarding access to data, the article found that publicity and reporting need to improve in the Caribbean. The author engaged with all main sources, especially local ones, at different stages of each project. PPPs in the Caribbean are not exempt when it comes to budgetary decisions.

(d) Ravi (2019) focuses on the evolution of ports and the growth of the private sector in PPP ports. The article carefully defines all terms in its discussion. It details a history of shipping and the use of ports. This case study on ports notes they represent "pedestals of the state wealth, security and superiority" [2]. It notes that ports arose from: (1) the rise of the container trade; (2) corporate alliances in the shipping business that created global hubs; and (3) efforts of ports to increase their structure and functions.

International trends in port governance, according to the article, arise from ports operating as one-stop shops. The article identifies the following trends in ports: (1) smart ports use transformative technology, data and robotics to redefine ports (such as a hyperloop); (2) better use of data, such as finding cost efficiency for capacity sensing, route optimization, energy management, and fault detection; (3) forcing ports to find more sustainable solutions and consider new approaches; and (4) energy hubs, where leading ports become centers for off-shore wind energy and refineries that transform waste into energy. Despite these technological achievements, the article raises concerns that protectionist and anti-globalization rhetoric could put ports at risk. Nonetheless, there is a strong belief in the conclusion of the article for the "immense potential for growth" in Asian countries, notably China and Indonesia, which could "emerge as future hubs of shipping and trade" [2].

(e) Fredouet, Guerin, and Despleb (2016) note through their survey and case study of four of France's ports, that productivity of these ports is quite low in comparison to its competitors. There also is a lack of good infrastructure connecting the ports to the central part of the country's interior. This, according to the authors, hinders the ability of these ports to serve as gateways to the European market.

To gather information for its analysis of ports in France, the article focuses on four French ports (Marseilles, Dunkirk, Rouen, Le Havre). This article relies upon industry surveys to explain successfully implemented PPPs. Noting there is no global approach to evaluating PPPs, the article relies upon the honesty of its survey respondents. The research questions focus on: (1) the motivation for PPPs, (2) characteristics of PPPs, and (3) evaluation of PPPs. In all four cases, implementation proved to be context-specific (e.g., the number of involved partners (Dunkirk), nature (Rouen) and level (Marseilles) of partner involvement, tightness of cooperation between partners (Le Havre)) [6].

But interestingly, the article appears to neglect directly defining PPPs. Rather, it discusses several ways PPPs can be successful. These are when: (1) the public authority 
invests in (mostly infrastructure) resources, which it makes available to the terminal operators; and (2) private partners invest in complementary (mostly superstructure) resources and operate the terminal(s). It mentions how outside factors, such as technology and artificial intelligence, aid PPP structures. In addition, "for effective partnership governance, [the article states] it is imperative to reduce the power asymmetry, develop horizontal coordination, and enhance public managers' capacity for effectively handling inter-organizational relationships" [6].

Noting the limits of its research, the article suggests questioning other partners (not just public authorities) in PPPs to determine any variances or convergences in the relationships. This research also follows a qualitative-based method, relying upon just four ports. To remedy this, the article suggests collecting data from more sources (including other ports), using a multiple-choice questionnaire, and undertaking a quantitative data analysis of information gleaned from these surveys. This could help explain PPP implementation better.

Overall, this article contributes to a better understanding of the "whys" and "hows" of PPP implementation. Public authorities, according to this article, fairly agree on what the conditions are for a given PPP to be successful: "the quality of each partner's contribution, a collective interest-aware behavior of all partners, and actual individual- and port- level benefits from the partnership" [6]. Thus, main motivations for implementing PPPs, according to the article, are "enhancement of port competitiveness, the search for better competencies, and the reinforcement of financial capacities." [6]

For China, Ravi (2019) discusses how the government is a role model and does not interfere with ports. Perhaps, they operate as a joint venture as stated. And these ports operate efficiently. To support this, the article notes the Port of Hong Kong, for instance, has the lowest service charges in the world. It notes that the private entity handles expansion projects and technology updates, while the public authority handles water depth in the port (so as to protect the public interest). Furthermore, an investor-friendly approach, confidence on the demand side dynamics and government non-interference help make this port successful.

In Panama, Brazil, and Mexico, PPPs are important. Panama, a strategically located country, benefits from using PPPs, particularly due to the interest from international organizations. Brazil and Mexico began privatization of its ports in the early 1990s and each have had success in their privatization efforts.

Cayman Islands, as mentioned in Estruch's article, is very new to PPPs. There is a general lack of experience in the Caribbean with PPPs and lack of infrastructure. There also are fiscal restraints and tax limitations that encourage innovative ways for initial investments. So, PPPs can be an attractive structure. There also is an effort to gain outside experience and education on PPPs.

South Korea is a model country for PPPs, according to Yareth Vargas Lopez and Lee (2019). Referencing a long history with PPPs, the article does not fully disclose the basis for choosing South Korea. This is quite relevant to making such a selection, and thus understanding the importance of South Korea in understanding PPPs. 
Columbia, according to Chechurina and Grin (2020), had inefficient ports, until a financial crisis forced change. The government enacted laws and brought investment into its ports. Its primary port, Port of Cartagena, has become one of the "best container terminals" in the Caribbean. It also is an exemplary PPP.

Assessment of PPPs and Ports and Their Application to Ukraine.

As Ukraine charts its path forward, it must examine how other countries have utilized PPP structures to grow and modernize their ports. Part of this stems from government policy and how accommodating it is. Ukraine has countless administrative bodies overseeing ports and several involved with PPPs. This is in addition to laws and regulations. It is important to avoid any mixed messaging arising from this.

It is also paramount Ukraine learn from other countries and not repeat other countries' mistakes. For instance, Ukraine has a dedicated agency for PPPs, State Organization Agency on Support Public-Private Partnership (known as "the PPP Agency") within the Ministry of Economy of Ukraine. There also is a PPP Management office (SPLINO) within the Ministry of Infrastructure to ensure the development of PPPs in Ukraine. The Ukrainian Sea Ports Authority (seaports) and the State Service for Marine and River Transport of Ukraine (regulates sea and river transport, including inland ports) are the primary sea and river port regulators. With the enactment of the Law on Inland Waterway Transport in January 2021 (to be effective in January 2022), Ukraine aims to streamline its oversight of waterways and transport. In addition, the National Transport Strategy of Ukraine until 2030 and the Strategy for the Development of Seaports of Ukraine until 2038 also aim to increase concession projects in ports. The Ministry of Infrastructure has already identified five ports for concession projects in Ukraine under the guise that "implementation of publicprivate partnership projects will promote the development of the maritime industry, attract investment and modernize the fixed assets of enterprises" [7].

In examining other countries, these articles looked at a range of countries.

Unlike France, Ukraine must integrate its ports with long-distance access to the rest of Ukraine and into the EU. This can only help support the ports. It also needs to work with port operators and private entities to improve port competitiveness. Other factors are the quality of the partners' competencies. This impacts the productivity and profitability of the ports. Of note in France is that private companies likely are better able to meet shorter financing deadlines than the public sector. This is even more reason for Ukraine to allow qualified partnerships with private entities at its ports.

Getting the Ukrainian government intimately involved similar to the joint venture approach by China could harken back to the days of the Soviet Union. This would probably not be ideal. Furthermore, with the amount of oversight in Ukraine, a joint venture seems unnecessary when the public authority in a PPP could adjust fees or taxes charged to concessioners to change the degree of control.

Columbia's economic problems forced the opening of its ports. Ukraine's path to privatizing its ports, seeking foreign investment and liberalizing control of its ports, is similar to Columbia. Given the success in the Port of Cartagena, Ukraine could look to this as an example to follow. 
Following the example of the Cayman Islands would be useful, as Ukraine is also a country new to PPPs. Many of its regulators learn about PPPs and Ukraine could have its regulators gain more insight on PPPs through training programs. Ukraine must, unlike Cayman Islands, not allow projects to be exempt from its PPP rules and regulations. It must be able to rely upon its rules and regulation governing PPP projects.

Ukraine could look to the success in Latin America, notably Panama. Ukraine, after all, has a strategic location between the European Union and the Middle East/Asia (similar to Panama's location between the Atlantic and Pacific Oceans). More importantly, existing infrastructure developed in Soviet times remains underutilized today. This has the attention of international institutions. Its strategic location only helps.

There are many possibilities for Ukraine. Having clear and transparent rules of the road for ports to utilize PPP structures is paramount. At the same time, Ukraine must not micromanage or allow public authorities to interfere with the private management of ports. There also must be relevant skills to understand the economics of PPPs for ports. In other words, Ukraine must maximize the utility of PPPs so the private sector continues to express interest in developing infrastructure of ports. Having agencies dedicated to promoting PPPs in Ukraine can only help. All these experiences provide Ukraine with valuable information in its efforts to bring PPPs to ports.

Prospects for further research are expected to change: trade routes, the competitive position of ports, ecosystems and cargo distribution. Each affected by underlying trends.

\section{References}

1. Panades-Estruch, Laura. (March 2021), Vol. 24 No. 1, p. 71.

2. Ravi, Dr Lekha. (July 2019). Vol. 4, Issue 7, p.349.

3. Chechurina, M N and Grin, A A. (August 2020). "Public Private Partnership in Management of Ports of the World." IOP Conference Series Earth and Environmental Science, 539(1), p. 4 EES Table 2.

4. Yareth Vargas Lopez, Erendira and Lee, Shin-Kyuo. (June 2019) "Public-Private Partnerships in Mexico, Panama, and Brazil: A Focus on Port Performance." Journal of Korea Trade, Vol. 23, No. 4, p. 22 referencing Hoffmann, J. (2001), "Latin American Ports: Results and Determinants of Private Sector Participation", International Journal of Maritime Economics, 3(2), p. 226 (p.24-26).

5. Panades-Estruch, Laura. (March 2021) "Public-Private Partnerships in Transport: A Critical Assessment of the Caribbean." Public Administration and Policy: An Asia-Pacific Journal, Vol. 24 No. 1, p. 67 refencing Cayman Islands Ministry of District Administration, Tourism and Transport, 2017.

6. $\quad$ Panades-Estruch, Laura. (March 2021), Vol. 24 No. 1, p. 67 - 71.

7. Fredouet, Charles H., Guerin, Frank, and Desplebin, Olivier. (January 2016). 6(1), p. 36 referencing Singh, A., \& Prakash, G. (2010). "Public-Private Partnerships in Health Services Delivery: A Network Organizations Perspective." Public Management Review, 12(6), pp.829-856, 42-49.

8. The Ministry of Infrastructure. (2021). "Concessions Projects in the Maritime Industry". https://mtu.gov.ua/content/koncesiyni-proekti-v-morskiy-galuzi.html 
Н. Бутенко, д.е.н., проф.,

Київський національний університет імені Тараса Шевченка, Україна

Е. Робінс, аспірант,

Київський національний університет імені Тараса Шевченка, Україна

\section{ДОСВІД МІЖНАРОДНОГО ДЕРЖАВНО-ПРИВАТНОГО ПАРТНЕРСТВА У ПОРТАХ ТА ЇХ ВІДНОШЕННЯ ДО УКРӒ̈НИ}

Метою цієї статті є огляд останніх міжнародних досліджень портів, які співпрацюють на умовах державно-приватного партнерства (ДПП). У цій статті розглядаються п'ять статей про порти Колумбії, Мексики, Бразилії, Карибського басейну (Кайманові острови), Китаю, Південної Кореї та Франції. Основні результати дослідження логічно розділені на наступні секції: (I) короткий зміст кожної статті; (II) критика статей, пов'язаних із зазначеними країнами; та (III) оцінка того, як це стосується та/або стосується України. Аналіз та оцінка кожної статті повинні краще інформувати про прогрес у розвитку ДПП та їх використання в портах України.

Ключові слова: державно-приватне партнерство, порти, Україна 